\title{
Structure of fish communities of French Polynesian coral reefs. I. Spatial scales
}

\author{
René Galzin \\ École Pratique des Hautes Études, Laboratoire de Biologie Marine et Malacologie, 55 Rue de Buffon, F-75005 Paris, France \\ and \\ Antenne Museum/EPHE, Centre de l'Environnement de Moorea, BP 1013, Moorea, Polynesie Française
}

\begin{abstract}
Patterns of fish distribution in French Polynesia were studied at several spatial scales: a single transect (with 280 species, 22 stations), on Moorea Island; several transects on the same island (171 species, 14 stations) and transects from 5 islands including Moorea (189 species, 10 stations). There were significant variations in abundance, richness and composition of species among sites within the single transect. There were also variations among similar habitats within one island and among islands. Differences among similar sites around one island were, however, small compared to variation across one transect at the same island. Possible explanations for these patterns are discussed.
\end{abstract}

\section{INTRODUCTION}

Problems of sampling coral reef fishes, and in particular the biases of different techniques, have been highlighted by several workshops of Australian (GBRMPA 1978, 1979), American (Barans \& Bortone 1983) and French (Harmelin-Vivien et al. 1985) scientists over the last decade. Effects of the scale of sampling have been emphasised a number of times (e.g. Sale 1980, Ogden \& Ebersole 1981) and are summarized well by Sale et al. (1985): 'Reef fish ecologists need to be able to determine the appropriate spatial scale at which to attack a particular question the frequency of sampling and the duration of experimental or monitoring programs which are necessary to answer specific questions effectively'

Most descriptions of reef fish communities come from the Carribbean, Australia and the Red Sea. By comparison, the fish of Central Oceania are poorly described. As part of an on-going study of fish on reefs in French Polynesia (Galzin 1985), I sampled a number of reefs to determine the spatial and temporal scales necessary to understand the ecology of the fish. Descriptions of these reef systems may be found in Delesalle et al. (1985).

In this article spatial distributions are described at 3 scales: (1) along a single, arbitrarily-chosen transect (Tiahura on Moorea Island), (2) among 5 transects representing different places on Moorea Island (includ- ing the Tiahura transect) and (3) among transects located in similar habitats on 5 islands (including Moorea Island) in French Polynesia.

\section{MATERIALS AND METHODS}

The Tiahura area (Galzin \& Pointier 1985) is situated in the northwest part of Moorea Island $\left(17^{\circ} 30^{\prime} \mathrm{S}\right.$, $149^{\circ} 50^{\prime} \mathrm{W}$ ) (Fig. 1). At Tiahura, the lagoon, which is $840 \mathrm{~m}$ wide on average, is characterised by a channel 5 to $12 \mathrm{~m}$ deep, separating the fringing reef from the barrier reef. This channel transfers water flowing continually over the barrier reef to a nearby ocean pass.

A coast-to-sea transect $1020 \mathrm{~m}$ long was divided into 22 sampling stations (Galzin \& Legendre 1987). Sampling was in bands measuring up to $200 \mathrm{~m}$ long and $50 \mathrm{~m}$ wide, centered at each station and done using 2 complementary techniques: visual observations and rotenone stations. For the first, the presence or absence of all readily visible species was noted at all stations during a haphazard swim of 45 min within each station. For the second, single coral patches of about $0.5 \mathrm{~m}^{3}$ were selected within each station and poisoned with rotenone. The presence/absence data (from visual surveys and poison stations) were analysed using the 'chronological clustering' of Legendre et al. (1985). This method partitions multi-species data series into 


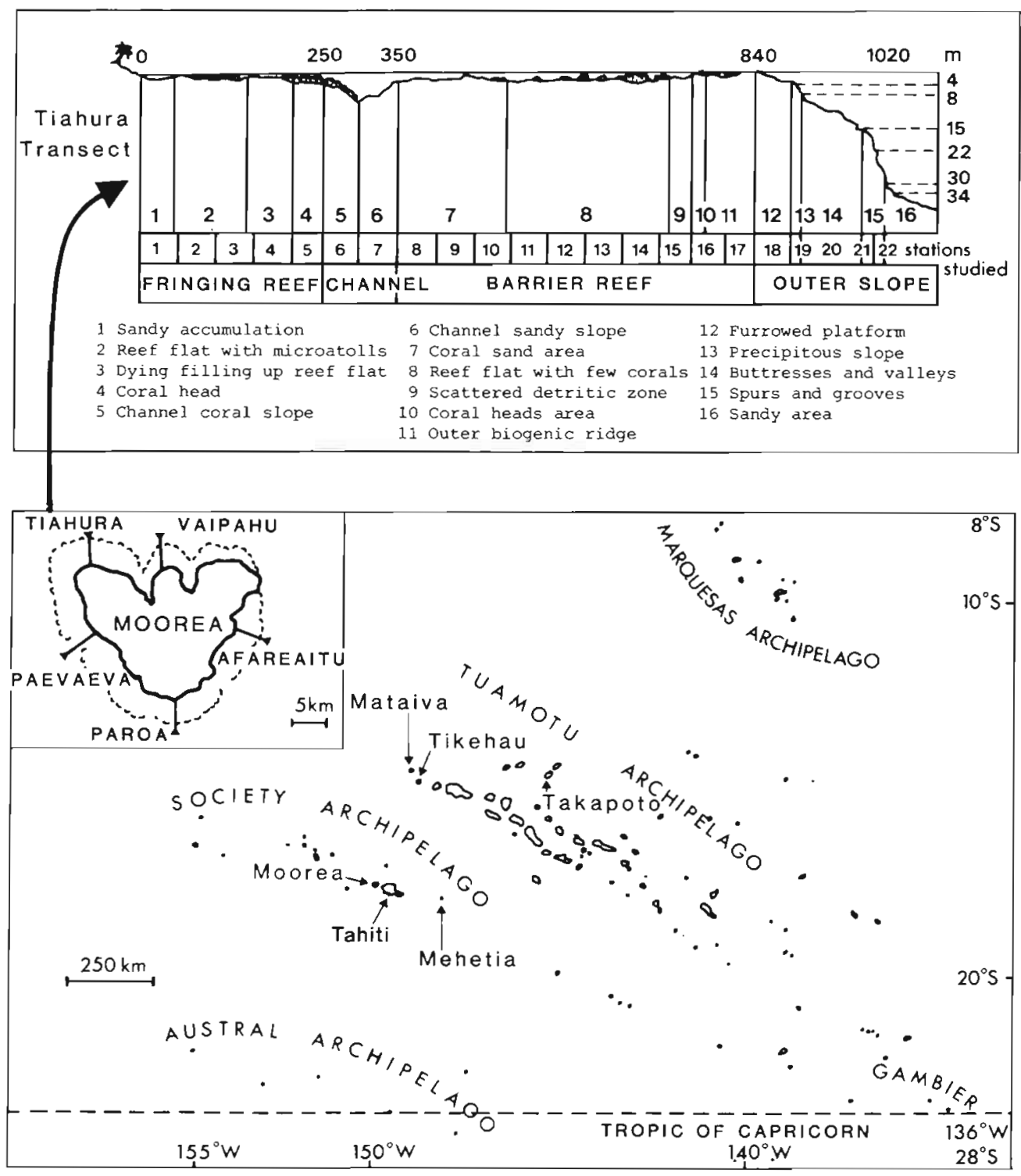

Fig. 1. French Polynesia showing Tahiti and the locations of the 5 islands studied. For Moorea Island the location of the 5 transects is shown together with the geomorphological zonation and the stations studied on the Tiahura transect

homogeneous segments by hierarchical agglomeration.

To compare sites around Moorea with the transect at Tiahura, I chose to study only 3 particular habitats on 4 other transects at locations around Moorea. These were the inner slope of the fringing reef, the reef flat with scattered coral patches and the outer slope at $12 \mathrm{~m}$ depth. The 4 transects were (Fig. 1):

(1) Afareaitu transect, located on the very exposed east coast and extending $1010 \mathrm{~m}$ into the lagoon, which reaches a depth of $35 \mathrm{~m}$. It was not possible to dive to seaward of this exposed coast; for this reason only 2 sites were sampled for this transect rather than the usual 3 .

(2) Paroa transect, located to the south of the island
This sandy transect measured $1610 \mathrm{~m}$ from the shoreline to the reef front and the water depth did not exceed $2 \mathrm{~m}$.

(3) Paevaeva lagoon, situated on the west coast and protected from the tradewinds. The transect measured approximately $1000 \mathrm{~m}$ from the beach to the reef front. Water in the lagoon was shallow $(<3 \mathrm{~m})$.

(4) Vaipahu transect, located between the Bays of Opunohu and Cook on the north coast. This transect was approximately $900 \mathrm{~m}$ long; the bottom was never deeper than $3 \mathrm{~m}$ and the barrier reef has become an offshore reef.

At each habitat, presence/absence data were collected during $45 \mathrm{~min}$ of visual observations as described above. The similarity matrix (Jaccard coeffi- 
cient of similarity) used on the presence/absence data was analysed by principal coordinate analysis and by flexible clustering, as suggested by Legendre \& Legendre (1983). In addition, at each site, a quantitative count of each species was made along a transect $50 \mathrm{~m}$ long and $2 \mathrm{~m}$ wide.

The choice of other islands (Fig. 1) to compare with Moorea was determined by previous studies (Delesalle et al. 1985) and logistic constraints. Three of the 4 chosen were atolls where the geomorphology differs greatly from that of Moorea. To make all the observations as comparable as possible among the sites, I studied only the outer reef slope at $12 \mathrm{~m}$ depth on each island. The sampling design and numerical analysis were the same as that used for the 5 transects on Moorea. The islands studied were:

Mehetia island $\left(18^{\circ} 10^{\prime} \mathrm{S}, 148^{\circ} 05^{\prime} \mathrm{W}\right)$, youngest of the Society archipelago (some hundreds of thousands of years). This is a volcanic island, $200 \mathrm{~m}$ in diameter and $435 \mathrm{~m}$ high.

Mataiva atoll (Delesalle 1985), located $300 \mathrm{~km}$ north of Tahiti $\left(14^{\circ} 55^{\prime} \mathrm{S}, 148^{\circ} 36^{\prime} \mathrm{W}\right)$. This is a small atoll, 10 by $5 \mathrm{~km}$, and has an unusual morphology: a wide atoll rim, almost continuous, allows only restrained oceanic exchanges. It has a reticulated lagoon divided into numerous basins by a network of slightly submerged reefs.

Takapoto atoll (Salvat \& Richard 1985), located $580 \mathrm{~km}$ northeast of Tahiti $\left(14^{\circ} 30^{\prime} \mathrm{S}, 145^{\circ} 20^{\prime} \mathrm{W}\right)$. This atoll is $17 \mathrm{~km}$ long and $5 \mathrm{~km}$ wide. It has no ocean passes and its rim is almost totally emerged. Takapoto is truly representative of the closed atoll ecosystem in the Tuamotu archipelago.

Tikehau atoll (Harmelin-Vivien 1985), located $300 \mathrm{~km}$ north of Tahiti $\left(15^{\circ} \mathrm{S}, 148^{\circ} 10^{\prime} \mathrm{W}\right)$. This atoll is almost circular (diameter nearly $28 \mathrm{~km}$ ). West of the atoll, on the leeward coast, the reef rim is interrupted by a $300 \mathrm{~m}$ wide pass which is at least $3.7 \mathrm{~m}$ deep. making Tikehau an open atoll.

To avoid confounding diel differences with spatial variation, all samples were gathered between 1000 and $1200 \mathrm{~h}$ between 1 Oct and 18 Nov 1982 for the single transect, between 7 and 16 Apr 1983 for the transects around Moorea and between 16 Sep and 7 Oct 1983 for the comparisons among islands.

The present work on spatial variations, the companion article on temporal scales (Galzin 1987) and another work on fisheries yield were all part of a study of communities of coral reef fish in French Polynesia. Logistical constraints limited opportunities of replicating sampling. To resolve some hypotheses developed in this paper, a proper sampling design would have consisted of: replicate samples within sites, multiple sites along each transect, replicate transects at each location and replicate locations at each island.

\section{RESULTS}

\section{Tiahura transect}

On the 22 stations of the Tiahura transect, 280 species were found. Groupings in these data were determined by a statistical test outlined in Galzin \& Legendre (1987). At the statistically significant level of alpha $<25 \%$, 4 groupings were determined: the sandy fringing reef community, the lagoon community, the reef front community and the outer slope community (Fig. 2). At alpha $=30 \%$, the lagoon community was further resolved into 4 groupings: an inner slope of the fringing reef, a channel, a sandy barrier reef and a reef flat with scattered coral patches.

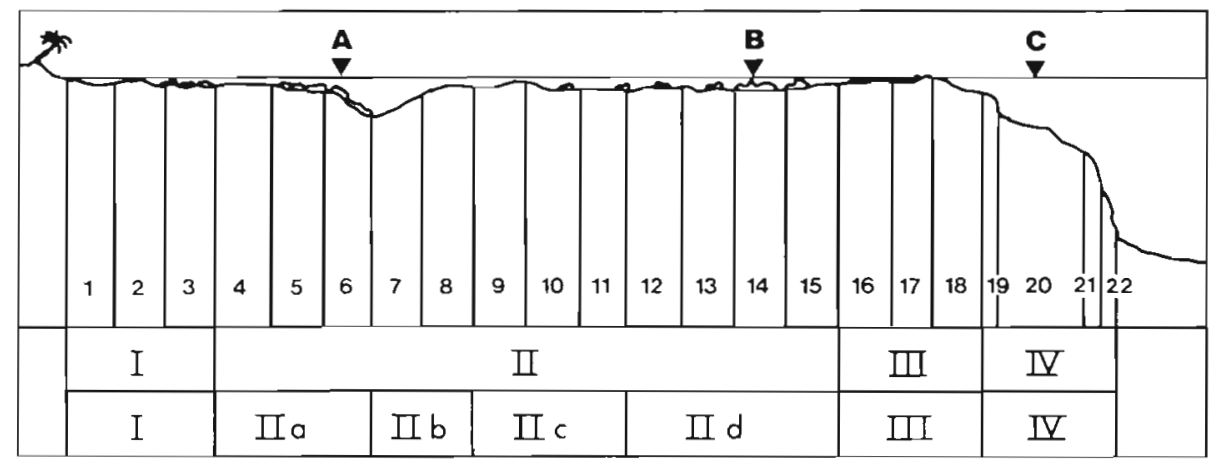

Fig. 2. Profile of the Tiahura transect showing the 22 sampling stations, the 4 groups of stations obtained by constrained clustering $(0.05<$ alpha $<0.25)$, and the 7 groups of stations obtained when alpha $=0.30$. Cuts in the data series are produced only when the null hypothesis is rejected by a randomization statistical test, at the alpha-level of significance. Habitats chosen for the study of sites within Moorea are also indicated: $\mathrm{A}$, inner slope of the fringing reef; $\mathrm{B}$, reef flat $150 \mathrm{~m}$ away from the crest; and C, outer slope at $12 \mathrm{~m}$ depth 
An a posteriori test was performed among the 7 groups of stations in order to detect affinities between non-adjacent segments of the partition (Galzin \& Legendre 1987). Significant relations were found among the lagoon community of the inner slope of the fringing reef, that of the sandy barrier reef and that of the reef front community $(6,8$ and 18 respectively in Fig. 2).

Among the 280 fish species recorded along the transect, 46 families were represented. The most important were the Labridae (40 species), the Pomacentridae (25), the Chaetodontidae (19), the Acanthuridae (19), the Apogonidae (14) and the Scaridae (13). The acanthurid Ctenochaetus striatus was found at all 22 sampling stations of the transect. Five other species were present in each of the 7 groups of stations ( $P$ seudopeneus multifasciatus, Chaetodon vagabundus, Stegastes nigricans, Stethojulis interrupta and Acanthurus triostegus) giving a total of 6 ubiquitous species ( $2 \%$ ). A total of 15 species $(5.4 \%$ ) were found at least once in each of the 4 major groups of stations ( 1 to 4 ) and these were considered to be species with ubiquitous distributions.

\section{Transects on Moorea Island}

At the 14 stations around Moorea, 171 species were censused (Table 1). Classification and principal coordinate analysis of these sites clearly resolved 2 major groupings: lagoon sites and reef slope ('ocean') sites (Fig. 3)

The differences between the lagoon and reef slope communities in the Tiahura transect was greater than the difference among all 5 lagoon transects around Moorea (Fig. 3)

Lagoon stations fell into 4 groups: those to the north of Moorea (Stns 1, 2,6 and 7); those to the west (Stns 3, 8 and 9); the Afareaitu fringing reef (Stn 5); and Stns 4 and 10 (Fig. 3).

Of the 171 species, Chaetodon citrinellus, Stegastes nigricans, Thalassoma hardwicke, Acanthurus triostegus and Canthigaster solandri were present at all lagoon stations and never present on the outer slope stations. On the other hand, 9 species (Anthias squamipinnis, Cephalopholis urodelus, Centropyge loriculus, Chromis vanderbilti, Chromis xanthura, Paracirrhites forsteri, Nemateleotris magnifica, Melichthys niger and one undescribed species of Balistidae) were always present at the outer-slope station but never found inside the lagoon. Only 5 species were present at all 14 stations: Pseudopeneus multifasciatus, Cheilinus trilobatus, Halichoeres hortulanus, Scarus sordidus and Ctenochaetus striatus.

\section{Comparison of 5 islands}

A total of 189 species were counted on the 10 outer slope stations distributed among 5 islands (Table 1). Classification and principal coordinate analysis divided these sites into 4 groups (Fig. 3): those on Moorea, Mehetia, Takapoto and Tikehau/Mataiva, respectively.

Amongst the 217 species counted in the 20 stations (Table 1), only one (Scarus sordidus) was found at all stations. Five species (Chaetodon citrinellus, Stegastes nigricans, Thalassoma hardwicke, Scarus psittacus and

Table 1. General results obtained during this study

\begin{tabular}{|c|c|c|c|c|c|c|c|c|c|c|c|c|c|c|c|c|c|c|c|c|}
\hline \multirow[b]{3}{*}{ Sampling station (Fig. 3) } & \multicolumn{14}{|c|}{ Moorea } & Meh. & \multicolumn{3}{|c|}{ Takapoto } & Tik. & Mat. \\
\hline & \multicolumn{10}{|c|}{ Lagoonal stations } & \multicolumn{10}{|c|}{ Outer slope of 5 islands } \\
\hline & 1 & 2 & 6 & 7 & 3 & 8 & 9 & 4 & 10 & 5 & 11 & 12 & 13 & 14 & 15 & 16 & 17 & 18 & 19 & 20 \\
\hline No. of species $100 \mathrm{~m}^{-2}$ & 34 & 28 & 26 & 28 & 15 & 20 & 16 & 22 & 25 & 31 & 44 & 32 & 27 & 37 & 46 & 46 & 41 & 47 & 43 & 47 \\
\hline No. of individuals $100 \mathrm{~m}^{-2}$ & 355 & 211 & 149 & 171 & 78 & 129 & 80 & 149 & 189 & 199 & 575 & 428 & 220 & 378 & 516 & 487 & 435 & 404 & 337 & 400 \\
\hline No. of species per community & \multicolumn{4}{|c|}{105} & \multicolumn{3}{|c|}{81} & \multicolumn{2}{|c|}{84} & 71 & \multicolumn{4}{|c|}{112} & 103 & \multicolumn{3}{|c|}{114} & \multicolumn{2}{|c|}{106} \\
\hline No. of species in Moorea study & \multicolumn{14}{|c|}{171} & \multicolumn{6}{|c|}{ - } \\
\hline $\begin{array}{l}\text { No. of species in } 5 \text { islands } \\
\text { outer slope study }\end{array}$ & \multicolumn{10}{|c|}{ - } & \multicolumn{10}{|c|}{189} \\
\hline Total no. of species & \multicolumn{20}{|c|}{217} \\
\hline Percentage of ubiquitous species & \multicolumn{20}{|c|}{6.91} \\
\hline
\end{tabular}




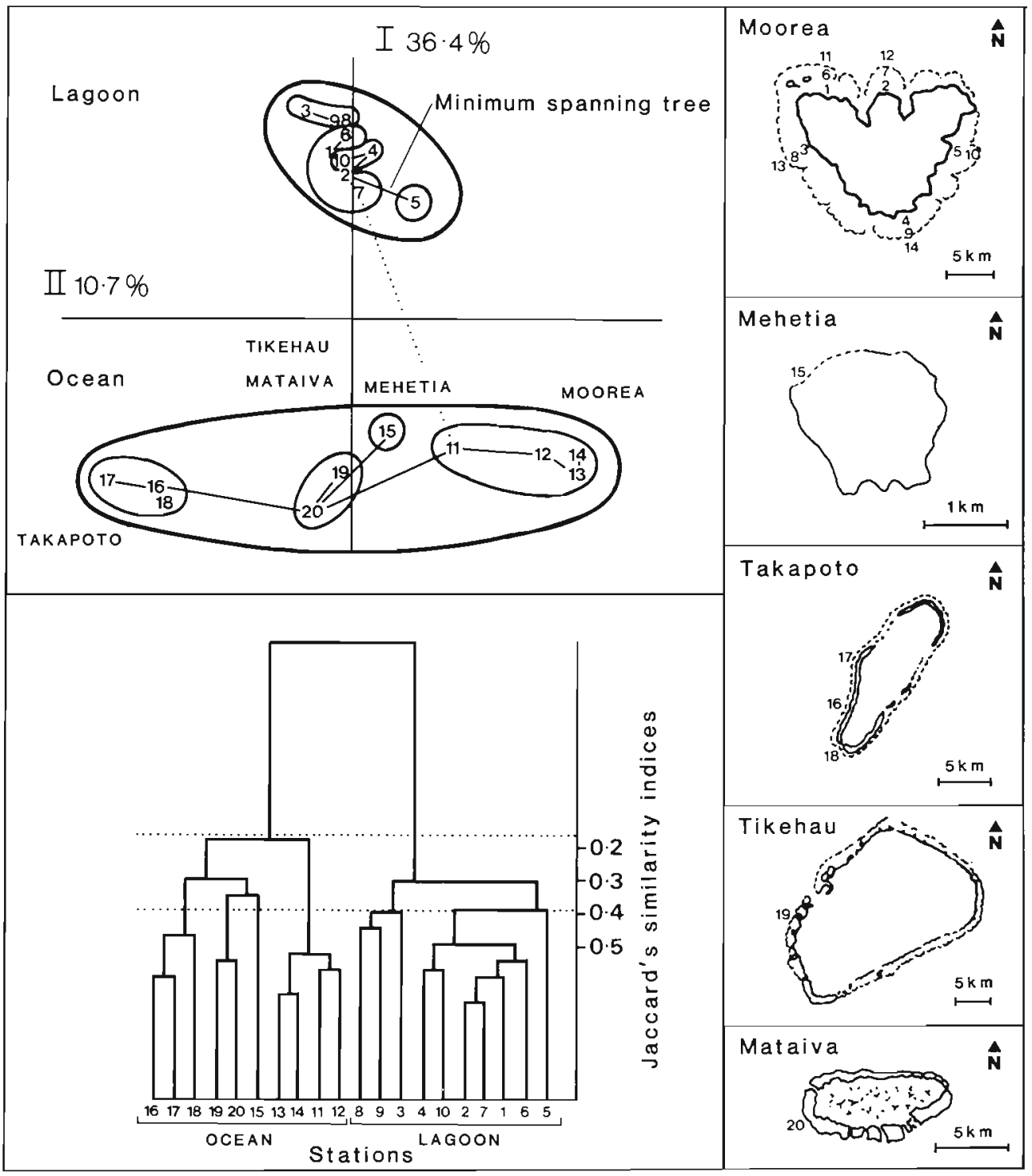

Fig. 3. Location of the sampling stations on each of the 5 islands, the first 2 axes of the principal coordinate analysis and a dendrogram derived from similarity matrices. Numbers refer to the 20 sampling sites distributed among the 5 islands

Canthigaster solandri) were always found in all the lagoonal stations and never in the outer slope stations. On the other hand, Centropyge loriculus, Chromis vanderbilti and Paracirrhites forsteri were always present in all the outer slope stations and never in the lagoonal stations.

Two points are of particular interest. First, the outer slope fish community of the atolls with a pass (Tikehau and Mataiva) were significantly more similar to each other than they were to the community of the closed atoll of Takapoto. Secondly, the outer slope fish community of the high island without a lagoon (Mehetia) was more similar to the outer slope community of atolls than to those of a high island with a lagoon (Moorea).

\section{DISCUSSION}

This work was designed to examine spatial variation in the structure of communities of fish of French Polynesian coral reefs at several different scales. Significant variations were found along a single cross-reef transect, among transects at different sites around one island and among the same kind of sites on different islands.

These observations suggest many possible causes of spatial variation. Two of great importance are the presence or absence of lagoons around high islands and the presence or absence of passes in atolls. I hypothesize that these geomorphological differences 
could be significant for the recruitment of coral reef fishes. Fish larvae and fish settlement have not yet been studied in French Polynesia, where nothing is yet known about the transition between the oceanic planktonic larval stages of fish and the benthic settlement of recruits. It does, however, seem likely that features such as passes would affect the distribution and composition of fish larvae. For example, lagoons may entrain larvae of some species in a way that is not possible on islands without a lagoon, such as Mehetia. A test of the importance of passes in atolls, and of lagoons of high islands, will require comparative studies that include several examples of each type. One factor which may cause, or at least maintain, the spatial patterns, could be habitat selection at the time of, or soon after, settlement. Habitat selection has been demonstrated by Williams (1980), Williams \& Sale (1981) and Eckert (1985), and discussed as a possible determinant of zonation of coral reef fishes by Russ (1984). Alternative explanations for my observed differences among islands include: the type of island studied (Williams 1982, Williams \& Hatcher 1983, Russ 1984), the length of the reef (Sale \& Williams 1984), the geographical position, and the degradation of the outer slope (Laboute 1985). The relative importance of these variables has not yet been demonstrated in French Polynesia.

The 5 transects around Moorea showed little difference in the organisation of fishes on the outer slope around a high island with a lagoon. On the other hand, there was a considerable difference between the lagoon transects: the northern transect had the greatest richness of species and the greatest total abundance of individuals, whereas the southern and western transects had the least. The results are comparable to those of Le Calvez \& Salvat (1980) obtained with Foraminifera and those of Lefevre (1985) for zooplankton.

There are 3 possible explanations for this pattern. First, the location of the stations relative to the tradewinds. The leeward stations (west and south) were in a shallow lagoon which was partly filled by sand, whereas the windward stations (east and north) were in an area that was very well developed geomorphologically with fringing and barrier reef separated by a deep channel. Second, the western pass in front of Afareaitu is large and in a very exposed area. Consequently, the morphology of the reef and the biological characteristics are those of very exposed areas like the outer slope. Although this station differs from other lagoonal stations its fish fauna was still more similar to those from other lagoonal stations than to those from outer slope stations. Third, it is likely that similarities between fish communities from the east barrier reef and south fringing reef can be explained by the similarities in coral types at these sites. At both places the dominant coral type was tabulate plates of Acropora.

While there were significant differences among similar sites around the one island, these differences were small compared to variation across one transect. Similar variations in the structure of fish communities among different zones within a single reef have been described elsewhere (e.g. Sale \& Dybdahl 1975, Gladfelter \& Gladfelter 1978, Gladfelter et al. 1980, Williams 1983). But only 2 other papers have presented data directly comparable to those described here: the work of Goldman \& Talbot (1976) on One Tree Island Reef on the Great Barrier Reef and that of Harmelin-Vivien (1979) on the Tulear Reefs in Madagascar. Despite the differences in methods, these authors' results are quite comparable to the present study in terms of numbers of ubiquitous species, and of species limited to a single habitat (Table 2)

The similarity of the lagoon community of the inner slope of the fringing reef, that of the sandy barrier reef and that of the reef front community, is of particular interest. The affinity between these 3 reef sections may be due to water circulation on the reef. The waves break against the reef-crest of Tiahura but wave-forces are stronger on the western side of the island. Some of

Table 2. Comparison of 3 coral reefs in the Indo-Pacific area, for percentage of ubiquitous species and of species restricted to a single habitat

\begin{tabular}{|c|c|c|c|c|c|c|}
\hline Reef & Partition of reef & $\begin{array}{l}\text { Total no. } \\
\text { of species }\end{array}$ & $\begin{array}{c}\% \text { of ubiquitous } \\
\text { species }\end{array}$ & $\begin{array}{l}\% \text { of species } \\
\text { restricted } \\
\text { to } 1 \text { habitat }\end{array}$ & $\begin{array}{l}\% \text { of species } \\
\text { restricted } \\
\text { to outer slope }\end{array}$ & Source \\
\hline $\begin{array}{l}\text { One Tree Island } \\
\text { (Australia) }\end{array}$ & 5 sections & 395 & 6.6 & 47.6 & 15.4 & $\begin{array}{l}\text { Goldman \& } \\
\text { Talbot (1976) }\end{array}$ \\
\hline $\begin{array}{l}\text { Tulear } \\
\text { (Madagascar) }\end{array}$ & 3 sections & 552 & 8.2 & 44.0 & 14.5 & $\begin{array}{l}\text { Harmelin-Vivien } \\
\text { (1979) }\end{array}$ \\
\hline $\begin{array}{l}\text { Moorea } \\
\text { (Polynesia) }\end{array}$ & 4 sections & 280 & 5.4 & 45.0 & 14.6 & $\begin{array}{l}\text { Galzin \& } \\
\text { Legendre (1987) }\end{array}$ \\
\hline
\end{tabular}


this ocean water flows through the channel resulting in a strong current. Twice a day, at low tide, this current decreases and only very rarely ceases. In this way, larvae could settle on either side of the channel and also on the crest. Each of these 3 sections seems to act as a 'reef front' receiving planktonic fish larvae from the ocean first. Other sections of the reef are then colonized by the fish that have settled on these reef fronts.

Other factors likely to influence distribution across the reef are (1) the percentage of living coral cover (Bell et al. 1985, Bouchon-Navaro et al. 1985, Galzin 1985), and (2) hydrodynamic activity (Galzin 1985). Some coral reef fish assemblages, at a particular spatial scale, appear to have structures correlated with the physical and biological complexity of the reef (Luckhurst \& Luckhurst 1978, Bell \& Galzin 1984, Sano et al. 1984). Bell \& Galzin 1984 showed that for the lagoonal fish communities of the atoll of Mataiva, the live coral cover was more important than the effect of distance between the stations sampled and the open ocean (Grovhoug \& Henderson 1978, Gladfelter et al. 1980).

This study has demonstrated considerable variation in the structure of fish communities at different scales in French Polynesia. It is now possible to choose an optimal spatial scale to answer a particular ecological question. Amongst the many hypotheses for the patterns observed, variations due to replication problems within sites, between transects and between locations, are not discussed and will be the focus of future research which will also determine the relative importance of several factors that might explain the existence and maintenance of the spatial patterns described here, and integrate these results with various patterns of temporal change on the structure of these assemblages (Galzin 1987).

Acknowledgements. I thank J. Bell, R. Bradley, L. Kaufman, A. J. Underwood, D. Williams and 3 anonymous reviewers who provided critical discussions and comments on earlier drafts of the manuscript. This work is a contribution to RCP 806 CNRS.

\section{LITERATURE CITED}

Barans, C. A., Bortone, S. A. (1983). The visual assessment of fish populations in the southeastern United States, 1982 Workshop. South Carolina Sea Grant Consortium, Atlanta, Georgia, Techn. Rep. 1, p. 1-52

Bell, J. D., Galzin, R. (1984). Influence of live coral cover on coral-reef fish communities. Mar. Ecol. Prog. Ser 15: 265-274

Bell, J. D., Harmelin-Vivien, M., Galzin, R. (1985). Large scale spatial variation in abundance of butterflyfishes (Chaetodontidae) on polynesian reefs. Proc. 5th Int. Coral Reef Cong. Tahiti 5: 421-426

Bouchon-Navaro, Y., Bouchon, C., Harmelin-Vivien, M.
(1985). Impact of coral degradation on a chaetodontid fish assemblage (Moorea, French Polynesia). Proc. 5th Int Coral Reef Cong. Tahiti 5: 427-432

Delesalle, B. (1985). Mataiva atoll, Tuamotu archipelago. Proc. 5th Int. Coral Reef Cong. Tahiti 1: 269-321

Delesalle, B., Galzin, R., Salvat, B. (1985) (ed.). French Polynesian coral reefs. Proc. 5th Int. Coral Reef Cong. Tahiti 1

Eckert, G. J. (1985). Settlement of coral reef fishes to different natural substrata and at different depths. Proc. 5th Int. Coral Reef Cong. Tahiti 5: 385-390

Galzin, R. (1985). Ecologie des poissons récifaux de Polynesie française. Thèse de Doctorat ès Sciences, Université des Sciences et Techniques du Languedoc

Galzin, R. (1987). Structure of fish communities of French Polynesian coral reefs. II. Temporal scales. Mar. Ecol. Prog. Ser. 41: 137-145

Galzin, R., Legendre, P. (1987). The fish communities of a coral reef transect. Pacif. Sci. (in press)

Galzin, R., Pointier, J. P. (1985). Moorea island, Society archipelago. Proc. 5th Int. Coral Reef Cong. Tahiti 1. 73-101

GBRMPA (1978). Great Barrier Reef Marine Park Authority, Workshop on reef fish assessment and monitoring. Workshop series 1, Heron Island, Australia, p. 1-64

GBRMPA (1979). Great Barrier Reef Marine Park Authority, Workshop on reef fish assessment and monitoring. Workshop series 2, Heron Island, Australia, p. 1-60

Gladfelter, W. B., Gladfelter, E. H. (1978). Fish community structure as a function of habitat structure on West Indian patch reefs. Rev. Biol. Trop. 26: 65-84

Gladfelter, W. B., Ogden, J. C., Gladfelter, E. H. (1980). Similarity and diversity among coral reef fish communities: a comparison between tropical western Atlantic (Virgin Islands) and tropical central Pacific (Marshall Islands) patch reefs. Ecology 61. 1156-1168

Goldman, B., Talbot, F. H. (1976). Aspects of the ecology of coral reef fishes. In: Jones, O. A., Endean, R. (ed.) Biology and geology of coral reefs. Academic Press, New York (Volume 3, Biology 2), p. 125-154

Grovhoug, J. G., Henderson, R. S. (1978). Distribution of inshore fishes at Canton Atoll. Atoll Res. Bull. 221. 99-157

Harmelin-Vivien, M. (1979). Ichtyofaune des récifs coralliens de Tuléar (Madagascar): écologie et relations trophiques. Thèse de Doctorat ès Sciences, Université Aix-Marseille II

Harmelin-Vivien, M. (1985). Tikehau atoll, Tuamotu archipelago. Proc. 5th Int. Coral Reef Cong. Tahiti 1: 211-266

Harmelin-Vivien, M., Harmelin, J. G., Chauvet, C., Duval, C., Galzin, R., Lejeune, P., Bamabé, G., Blanc, F., Chevalier, R., Duclerc, J., Lasserre, G. (1985). Evaluation visuelle des peuplements et populations de poissons: méthodes et problèmes. Rev. Ecol. (Terre Vie) 40: 467-539

Laboute, P. (1985). Evaluation des dégâts causés par les passages des cyclones de 1982-1983 en Polynésie française sur les pentes externes des atolls de Tikehau et de Takapoto (archipel des Tuamotu). Proc. 5th Int. Coral Reef Cong. Tahiti 3: 323-329

Le Calvez, X., Salvat, B. (1980). Foraminifères des récifs et lagons coralliens de Moorea, île de la Société. Cah. Micropal. 4: 1-15

Lefèvre, M. (1985). Spatial variability of zooplanktonic populations in the lagoons of a high island (Moorea, French Polynesia). Proc. 5th Int. Coral Reef Cong. Tahiti 6: 39-45

Legendre, L., Legendre, P. (1983). Numerical ecology developments in environmental modelling 3. Elsevier, Amsterdam

Legendre, P., Dallot, S., Legendre, L. (1985). Succession of 
species within a community: chronological clustering, with applications to marine and freshwater zooplankton. Am. Nat. 125: 257-288

Luckhurst, B. E., Luckhurst, K. (1978). Analysis of the influence of substrate variables on coral reef fishes communities. Mar Biol. 49: 317-323

Ogden, J. C., Ebersole, J. P. (1981). Scale and community structure of coral reef fishes: a long term study of a large artificial reef. Mar. Ecol. Prog. Ser 4: 97-104

Russ, G. R. (1984). The distribution and abundance of herbivorous grazing fishes in the central Great Barrier Reef I. Levels of variability across the entire continental shelf. Mar. Ecol. Prog. Ser. 20: 23-34

Russ, G. R. (1984). Distribution and abundance of herbivorous grazing fishes in the central Great Barrier Reef. II. Patterns of zonation of mid-shelf and outer-shelf. Mar. Ecol. Prog. Ser. 20: $35-44$

Sale, P. F. (1980). The ecology of fishes on coral reefs Oceanogr. mar. Biol. A. Rev. 18: 367-421

Sale, P. F., Dybdahl, R. (1975). Determinants of community structure for coral reef fishes in an experimental habitat. Ecology 56: 1343-1355

Sale, P. F., Jones, G. P., Choat, J. H., Leis, J. M., Thresher, R. E., Williams, D. McB. (1985). Current priorities in ecology of coral reef fishes. Search 16 (9-12): 270-274

Sale, P. F., Williams, D. McB. (1984). Temporal variability in the community structure of fish on coral patch reefs and the relation of community structure to reef structure. Ecology 65 (2): 409-422

Salvat, B., Richard, G. (1985). Takapoto atoll, Tuamotu archipelago. Proc. 5th Int. Coral Reef Cong. Tahiti 1. 323-377

Sano, M., Shimizu, M., Nose, Y (1984). Changes in structure of coral reef fish communities by destruction of hermatypic corals: observational and experimental views. Pacif. Sci. 38: $51-79$

Williams, D. McB. (1980). Dynamics of the Pomacentrid community on small patch reefs in One Tree Lagoon (Great Barrier Reef). Bull. mar. Sci. 30: 159-170

Williams, D. McB. (1982). Patterns in the distribution of fish communities across the Central Great Barrier Reef. Coral Reefs 1: 35-43

Williams, D. McB. (1983). Longitudinal and latitudinal variation in the structure of reef fish communities. In: Baker et al. (ed.) Proc. Inaugural Great Barrier Reef Conf., Townsville: $265-270$

Williams, D. McB., Hatcher, A. L. (1983). Structure of fish communities on outer-slopes of inshore, mid-shelf and outer shelf reefs of the Great Barrier reef. Mar Ecol. Prog. Ser. 10: $23-34$

Williams, D. McB., Sale, P. F. (1981). Spatial and temporal patterns of recruitment of juvenile coral reef fishes to coral habitats within One Tree Lagoon, Great Barrier Reef. Mar. Biol. 65: 245-253

This article was presented by Dr A. J Underwood; it was accepted for printing on September 23, 1987 